6 Matricardi PM, Rosmini F, Ferrigno L, Nisini R, Rapicetta M, Chionne P, et al. Cross-sectional retrospective study of prevalence of atopy among Italian military students with antibodies against hepatitis A virus. $B M I$ 1997;314:999-1003.

7 Matricardi PM, Rosmini F, Riondino S, Fortini M, Ferrigno L, Rapicetta $\mathrm{M}$, et al. Exposure to foodborne microbes versus airborne viruses in rela$\mathrm{M}$, et al. Exposur to foodborne nicrobes versus airborne viruses in relation to atopy

Sigurs N, Bjarnason R, Sigurbergsson F, Kjellman B, Bjorksten B. Asthma and immunoglobulin $\mathrm{E}$ antibodies after respiratory syncytial virus bronchiolitis: a prospective cohort study with matched controls. Pediatrics 1995;95:500-5.

9 Stein RT, Sherrill D, Morgan WJ, Holberg CJ, Halonen M, Taussig LM, et al. Respiratory syncytial virus in early life and risk of wheeze and allergy by age 13 years. Lancet 1999:354:541-5.

10 Bergmann RL, Bergmann KE, Lau-Schadendorf S, Luck W, Dannemann A, Bauer CP, et al. Atopic diseases in infancy. The German multicenter atopy study (MAS-90). Pediatr Allergy Immunol 1995;5(suppl 1):19-25.

11 Weidtman V. Diagnoseschlüssel für die Pädiatrie. Vol 11. In: Hellbrügge T, ed. Documenta Pädiatrica. Lübeck: Hansesches Verlagskontor, 1982

12 Niggemann B, Illi S, Madloch C, Völkel K, Lau S, Bergmann R, et al
Bronchial histamine challenges in 7 year old children: a PC20FEV1 below $1.0 \mathrm{mg} / \mathrm{ml}$ discriminates between symptomatic and nonsymptomatic children. Eur Respir J (in press).

13 Nicolai T, von Mutius E, Reitmeir P, Wjst M. Reactivity to cold air hyperventilation in normal and in asthmatic children in a survey of 5,697 school children in Southern Bavaria. Am Rev Respir Dis 1993;147:565-72. ciates. Association of non-wheezing lower respiratory tract illnesses in early life with persistently diminished serum IgE levels. Thorax 1995;50:1067-72

15 Farooqi IS, Hopkin JM. Early childhood infection and atopic disorder. Thorax 1998;53:927-32.

16 Shaheen SO, Aaby P, Hall AJ, Barker DJP, Heyes CB, Shiell AW, et al. Measles and atopy in Guinea-Bissau. Lancet 1996;347:1792-6.

17 Ball TM, Castro-Rodriguez JA, Griffith KA, Holberg CJ, Martinez FD, Wright AL. Siblings, day-care attendance, and the risk of asthma and wheezing during childhood. N Engl J Med 2000;343:538-43.

18 Whitley RJ. Herpes simplex viruses. In: Fields BN, Knipe DM, eds Virology. 2nd ed. New York: Raven Press, 1990:1849.

(Accepted 27 November 2000)

\title{
Antibiotic susceptibility of streptococci and related genera causing endocarditis: analysis of UK reference laboratory referrals, January 1996 to March 2000
}

\author{
Alan P Johnson, Marina Warner, Karen Broughton, Dorothy James, Androulla Efsratiou, \\ Robert C George, David M Livermore
}

A combination of penicillin and gentamicin is recommended for streptococcal endocarditis by both the Endocarditis Working Party of the British Society for Antimicrobial Chemotherapy and the American Heart Association, with vancomycin replacing penicillin for those who are allergic to penicillin. ${ }^{2}$ The Public Health Laboratory Service's Antibiotic Resistance Monitoring and Reference Laboratory and Streptococcus and Diphtheria Reference Unit routinely test bacteria referred from cases of endocarditis from a wide range of hospitals, representing about $15 \%$ of all UK isolates from endocarditis. We retrospectively analysed the species distribution and antimicrobial susceptibility of streptococci and related bacteria from patients with endocarditis received over 4.25 years; enterococci have been reviewed previously. ${ }^{3}$

\section{Methods and results}

Isolates from confirmed cases of endocarditis referred between January 1996 and March 2000 were identified from the reference laboratory's database, which provides antibiotic susceptibility as minimum inhibitory concentrations of each antibiotic for each isolate. Isolates were categorised as susceptible or resistant using published criteria. ${ }^{4}$

Data were available for 607 non-duplicate isolates, comprising 26 genera or species, referred from 168 UK hospitals (table). Most (86\%) of the isolates were "viridans" group streptococci, which are documented as the commonest agents of endocarditis. ${ }^{5}$ Five species accounted for over two thirds of the isolates. Among these, $13 \%$ of Streptococcus oralis isolates, $14.5 \%$ of $S$ sanguis, and $5.5 \%$ of $S$ gordonii had reduced penicillin susceptibility (minimum inhibitory concentrations greater than $0.125 \mathrm{mg} / \mathrm{l}$ ), whereas all $S$ bovis type I and $S$ mutans isolates were susceptible. Other species and genera comprised fewer than 20 isolates each, precluding meaningful calculation of percentage resistance. None the less, it was notable that both isolates of Abiotrophia defectiva and six of 15 isolates of $A$ adjacens had reduced susceptibility to penicillin. All isolates of $S$ pneumoniae and Lancefield groups A, B, C, and G streptococci were susceptible to penicillin.

Overall, $88.8 \%$ of the isolates were susceptible to penicillin (minimum inhibitory concentrations $\leqslant 0.125$ $\mathrm{mg} / \mathrm{l}$ ), and minimum inhibitory concentrations of 0.25 $\mathrm{mg} / \mathrm{l}$ were seen for another $4.4 \%$. Minimum inhibitory concentrations of 4-8 mg/l were seen for only seven isolates $(1.2 \%)$. All of the isolates were susceptible to vancomycin and teicoplanin (minimum inhibitory concentrations 0.5 to $2 \mathrm{mg} / \mathrm{l}$ ) and none had high level resistance (minimum inhibitory concentration greater than $2000 \mathrm{mg} / \mathrm{l}$ ) to gentamicin.

\section{Comment}

Although the clinical data available to our reference laboratory are sometimes limited and there is a potential for submission bias, we believe that our analysis is the most comprehensive possible for streptococcal endocarditis. The data confirm the dominance of "viridans" streptococci and indicate that whereas a few $(1.2 \%)$ have substantial penicillin resistance, most remain fully susceptible. Some guidelines advocate that endocarditis of a native valve caused by streptococci that are susceptible to penicillin should be treated for two weeks with penicillin plus gentamicin, provided patients lack thromboembolic disease and cardiac risk factors, have small vegetations, and respond clinically within the first week. ${ }^{1}$ In patients not fulfilling these criteria or with infection of a prosthetic valve, four weeks of penicillin plus gentamicin is recommended. Treatment for at least four weeks is also advocated for

\section{Antibiotic \\ Resistance \\ Monitoring and Reference \\ Laboratory, Central Public Health \\ Laboratory, Colindale, London NW9 5HT \\ Alan P Johnson \\ clinical scientist \\ Marina Warner biomedical scientist Dorothy James data administrator David M Livermore clinical scientist}

continued over

BMJ 2001;322:395-6

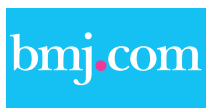

This article is part of the BMJ's randomised controlled trial of open peer review. Documentation relating to the editorial decision making process is available on the BMJ's website 
Streptococcus and Diphtheria

Reference Unit,

Respiratory and

Systemic Infection

Laboratory, Central

Public Health

Laboratory

Karen Broughton

biomedical scientist

Androulla Efsratiou

clinical scientist

Robert C George

consultant

microbiologist

Correspondence to:

A P Johnson

Ajohnson@phls.

nhs.uk

Identification of 607 isolates from cases of endocarditis and their susceptibility to penicillin

\begin{tabular}{|c|c|c|c|c|c|c|c|c|c|c|}
\hline \multirow[b]{2}{*}{ Organism } & \multirow{2}{*}{$\begin{array}{c}\text { No (\%) of } \\
\text { isolates }\end{array}$} & \multirow{2}{*}{$\begin{array}{c}\text { No of } \\
\text { hospitals }\end{array}$} & \multicolumn{8}{|c|}{ No of isolates with indicated penicillin minimum inhibitory concentrations (mg/l) } \\
\hline & & & $\leqslant 0.06$ & 0.125 & 0.25 & 0.5 & 1 & 2 & 4 & 8 \\
\hline Streptococcus oralis* & $145(23.9)$ & 78 & 98 & 28 & 9 & 3 & 3 & & 3 & 1 \\
\hline Streptococcus sanguis* & $110(18.1)$ & 69 & 82 & 12 & 5 & 6 & 5 & & & \\
\hline Streptococcus gordonii ${ }^{*}$ & $55(9.1)$ & 41 & 50 & 2 & 2 & & & & 1 & \\
\hline Streptococcus bovis type I* & $54(8.9)$ & 39 & 53 & 1 & & & & & & \\
\hline Streptococcus mutans ${ }^{\star}$ & $51(8.4)$ & 39 & 50 & 1 & & & & & & \\
\hline Streptococcus mitis* & $28(4.6)$ & 24 & 18 & 3 & 1 & 1 & 2 & 2 & & 1 \\
\hline Lancefield Group B & $22(3.6)$ & 20 & 22 & & & & & & & \\
\hline Lancefield Group G & $19(3.1)$ & 19 & 19 & & & & & & & \\
\hline $\begin{array}{l}\text { Streptococcus } \\
\text { gallolyticus } \dagger\end{array}$ & $17(2.8)$ & 16 & 17 & & & & & & & \\
\hline Streptococcus vestibularis & $17(2.8)$ & 15 & 10 & 1 & 1 & 1 & 4 & & & \\
\hline Streptococcus parasanguis $^{*}$ & $16(2.6)$ & 15 & 5 & 5 & 4 & 1 & & 1 & & \\
\hline Abiotrophia adjacens & $15(2.5)$ & 15 & 6 & 3 & 4 & 1 & & & & 1 \\
\hline Streptococcus anginosus & $15(2.5)$ & 15 & 13 & 2 & & & & & & \\
\hline Gemella morbillorum & $10(1.6)$ & 10 & 9 & 1 & & & & & & \\
\hline Streptococcus salivarius & $7(1.2)$ & 6 & 5 & 1 & & & & 1 & & \\
\hline Streptococcus pneumoniae & $7(1.2)$ & 5 & 7 & & & & & & & \\
\hline Streptococcus intermedius & $5(0.8)$ & 5 & 5 & & & & & & & \\
\hline Gemella haemolysans & $4(0.7)$ & 4 & 3 & & & 1 & & & & \\
\hline Lancefield Group A & $3(0.5)$ & 3 & 3 & & & & & & & \\
\hline Abiotrophia defectiva & $2(0.3)$ & 2 & & & 1 & 1 & & & & \\
\hline Lancefield Group C & $2(0.3)$ & 2 & 2 & & & & & & & \\
\hline Streptococcus constellatus & $1(0.2)$ & 1 & 1 & & & & & & & \\
\hline Lactococcus spp & $1(0.2)$ & 1 & & & & 1 & & & & \\
\hline Streptococcus sobrinus* & $1(0.2)$ & 1 & 1 & & & & & & & \\
\hline All isolates & $607(100)$ & 168 & $479(78.9 \%)$ & $60(9.9 \%)$ & $27(4.4 \%)$ & $16(2.6 \%)$ & $14(2.3 \%)$ & $4(0.7 \%)$ & $4(0.7 \%)$ & $3(0.5 \%)$ \\
\hline
\end{tabular}

*Species included with "viridans" group of streptococci.

†Previously known as $S$ bovis type II.

patients with streptococci with reduced susceptibility to penicillin: the British Society for Antimicrobial Chemotherapy advocates penicillin plus gentamicin for four weeks when the minimum inhibitory concentration of penicillin exceeds $0.1 \mathrm{mg} / \mathrm{l}$; the American Heart Association advocates penicillin for at least four weeks, with gentamicin for the first two weeks if the minimum inhibitory concentration of penicillin is 0.25 $\mathrm{mg} / \mathrm{l}$ or for at least four weeks if it exceeds this value.

Although reduced susceptibility to penicillin was noted in about $11 \%$ of our isolates, with $1.2 \%$ substantially resistant, none showed resistance to vancomycin or high level resistance to gentamicin, which would abolish synergy in combined treatments. Although reduced susceptibility to penicillin has implications for the duration of treatment, penicillin and gentamicin remain appropriate for most patients, with vancomycin and gentamicin a universally active alternative for those who are allergic to penicillin or who have more resistant isolates.
Contributors: APJ conceived the idea for the project, collected and analysed the data, and drafted the paper; he will act as guarantor for the paper. MW performed the antibiotic susceptibility tests. $\mathrm{KB}$ and $\mathrm{AE}$ speciated the bacterial isolates. $\mathrm{DJ}$ assisted in collection and collation of the data. DML and RCG contributed to discussions.

Funding: Public Health Laboratory Service.

Competing interests: None declared.

1 Working Party of the British Society for Antimicrobial Chemotherapy. Antibiotic treatment of streptococcal, enterococcal, and staphylococcal endocarditis. Heart 1998;79:207-10.

2 Wilson WR, Karchmer AW, Dajani AS, Taubert KA, Bayer A, Kaye D, et al Antibiotic treatment of adults with infective endocarditis due to streptococci, enterococci, staphylococci, and HACEK microorganisms. JAMA 1995;274:1706-13.

3 Johnson AP, Warner M, Woodford N, Speller DCE, Livermore DM. Antibiotic resistance among enterococci causing endocarditis in the UK: analysis of isolates referred to a reference laboratory. BMJ 1998;317: 629-30.

4 Working Party of the British Society for Antimicrobial Chemotherapy. A guide to sensitivity testing. J Antimicrob Chemother 1991;27(suppl D):1-50.

5 Dyson C, Barnes RA, Harrison GA. Infective endocarditis: an epidemiological review of 128 episodes. J Infect 1999;38:87-93.

(Accepted 27 October 2000)

\section{One hundred years ago \\ Longevity in Spain}

If any one is ambitious to achieve the honour of centenarianism he might, if any trust is to be put in statistics, do worse than go and live in Asturias. The list of voters drawn up for the recent elections showed that there is a remarkable number of persons who have attained to a patriarchal length of days in that province of Spain. Each of the electoral districts of Langreo, Morcin, Grado, Villaviciosa, and Carreno has one centenarian; Siero and Oviedo have each two; Salas has electors aged respectively 101, 103, and 104; Cangas de Tineo has still more venerable triplets of
101, 105, and 106; Boal has two aged 101 and 102; Franeo one of 107; Valdes two of 105 and 107; Pitona two of 102 and 104; while Parres holds the record with three fine relics of antiquity, aged respectively 103,105 , and 107 . This single province therefore rejoices in no fewer than 28 centenarians in a total population of 600,000 . The fact speaks well for the excellence of the climate of Asturias and for the vital stamina and healthiness of life of its inhabitants.

(BMJ 1901;i:418) 